\title{
Impacts of poplar and alder on soil carbon in pasture-tree systems
}

\author{
G.B. DOUGLAS ${ }^{1}$, R.E. VIBART ${ }^{1}$, A.D. MACKAY ${ }^{1}$, M.B. DODD ${ }^{1}$ and I.R. McIVOR ${ }^{2}$ \\ ${ }^{1}$ AgResearch Grasslands, Private Bag 11008, Palmerston North, New Zealand \\ ${ }^{2}$ Plant and Food Research, Private Bag 11030, Palmerston North, New Zealand \\ grant.douglas@agresearch.co.nz
}

\begin{abstract}
Wide-spaced trees on pastoral land (pasture-tree (PT) systems) are a widespread feature of many farmed landscapes. They offer the potential to increase carbon (C) storage, with implications for reducing atmospheric $\mathrm{CO}_{2}$-C. The effect of PT systems on soil C stocks to $1 \mathrm{~m}$ depth was determined for trees aged 14-16 years at densities of 73-111 stems per hectare at four North Island sites (two with poplar, two with alder). Across sites, mean soil $\mathrm{C}$ concentration was $1.9-8.5 \%$ and mean total soil $\mathrm{C}$ mass was $120-455$ tonnes $\mathrm{C} / \mathrm{ha}$. For alder systems, total C mass of PT was $37 \%$ less than adjacent pasture (Open) at Poukawa (120 versus 189 tonnes C/ha), whereas at Ruakura, there was no significant difference between systems. Total $\mathrm{C}$ mass of PT systems involving poplar did not vary significantly from adjacent Open systems at Tikokino (328 versus 352 tonnes $\mathrm{C} / \mathrm{ha}$ ) and Woodville (154 versus 202 tonnes $\mathrm{C} / \mathrm{ha}$ ). Soil at $0.3-1.0 \mathrm{~m}$ depth comprised up to half of total C mass. Results suggested that poplar and alder had different effects on soil C.
\end{abstract}

Keywords: pastoral hill country, wide-spaced trees, carbon sequestration, greenhouse gas (GHG) mitigation

\section{Key messages}

- Soil C mass (0-1 m depth) of pasture-tree (PT) systems involving poplar and alder was not significantly different from that of adjacent open pasture, except at one of two sites with alder where the PT system had $37 \%$ less soil C than open pasture.

- Up to $50 \%$ of the $\mathrm{C}$ mass at $0-1 \mathrm{~m}$ soil depth resides deeper than $0.3 \mathrm{~m}$.

\section{Introduction}

The carbon (C) in soil organic matter is a major component within the global C cycle (Eswaran et al. 1995; Lal 2004). Comparative estimates of organic C contained in living biomass $(560 \mathrm{Pg})$ and atmospheric $\mathrm{CO}_{2}-\mathrm{C}(760 \mathrm{Pg})$ indicate that a small shift in the soil organic $\mathrm{C}$ pool has the potential to have a large impact on atmospheric concentrations (Lal 2004). This represents a potential greenhouse gas (GHG) mitigation option for key primary industries in New Zealand.

On pastoral hill country, wide-spaced trees (pasturetree (PT) systems) have been a prominent feature for 50+ years (Wilkinson 1999; McIvor et al. 2011).
The primary purpose of the trees is to reduce the occurrence of mass movement erosion processes such as shallow landslides (Douglas et al. 2013) through altering soil strength and hydrological patterns. The tree species used are predominantly poplar (Populus spp.) and willow (Salix spp.) (McIvor et al. 2011), with other species used including wattle (Acacia spp.), gum (Eucalyptus spp.) and alder (Alnus spp.) (Van Kraayenoord \& Hathaway 1986). Mature tree density in PT systems is usually less than 50 stems per hectare (sph), but can vary considerably with risk and type of erosion, tree survival, and the extent of thinning if high densities were planted.

There has been increasing interest in the potential of trees at varying densities to sequester $\mathrm{C}$ in above- and below-ground biomass to counter increasing atmospheric concentrations of GHGs (Dube et al. 2012; PérezCruzado et al. 2012; Baah-Acheamfour et al. 2014). In the few studies that have determined soil $\mathrm{C}$ mass in PT systems, sampling has been to soil depths less than 300 $\mathrm{mm}$. In a Manawatu poplar-pasture system, maximum soil organic $\mathrm{C}$ content $(0-75 \mathrm{~mm}$ depth) was $<35$ tonnes $\mathrm{C} / \mathrm{ha}$ and $\mathrm{C}$ content was similar or less in PT than in paired Open pasture plots (Guevara-Escobar et al. 2002). In contrast, the organic $\mathrm{C}$ of soil (0-100 $\mathrm{mm}$ depth) averaged over 12 sites in central Alberta, Canada, was higher in a poplar silvopastoral system $(81.3 \mathrm{~g} / \mathrm{kg})$ than in adjacent open pasture $(53.1 \mathrm{~g} / \mathrm{kg}$ ) (Baah-Acheamfour et al. 2014). Differences in soil C in PT compared with Open systems on similar topography could be because of factors such as tree species/clone, stand age, tree density, grazing management, cultivation history and soil type.

Trees modify their local environment (Douglas et al. 2006a; Douglas et al. 2006b), impacting on inputs into the $\mathrm{C}$ cycle of pasture litter and root biomass, and contribute leaf litter and root biomass of their own (Young 1997). There is little information for PT systems on how deep in the soil profile trees influence soil C stocks, if they alter total $\mathrm{C}$ mass, or simply shift the distribution of soil C down the profile. Trees also modify the physical, chemical and biological properties of soils (GuevaraEscobar et al. 2002; Power et al. 2003; Douglas et al. 2006b), which in turn influences $C$ cycling.

This study aimed to determine if PT systems comprising trees at densities similar to those found on a range of pastoral landscapes accumulate more soil $\mathrm{C}$ than Open pasture systems to $1 \mathrm{~m}$ depth. Furthermore, it 
aimed to determine how responses vary between widespaced trees at geo-climatically different environments, and the impact of two different tree species.

\section{Materials and methods \\ Sites}

Four PT systems were selected on four different farm sites, comprising two in summer-moist (Ruakura, Waikato; Woodville, southern Hawke's Bay) and two in summer-dry (Poukawa and Tikokino, central Hawke's Bay) environments. The trees were components in partial radial planting designs at each site (Nelder 1962), which were established in September 1996 (Poukawa, Ruakura) or September 1998 (Tikokino, Woodville). The trial sites were located on land of $0-10^{\circ}$ slope angle and soils were silt loams, except at Tikokino, which was a sandy loam. Results reported are for trees near the outer perimeter of the Nelder designs at each site, which provided relatively low densities of $73 \mathrm{sph}$ at Poukawa, $111 \mathrm{sph}$ at Ruakura, $76 \mathrm{sph}$ at Tikokino and $67 \mathrm{sph}$ at Woodville. At these densities, the outer perimeters of the canopies of adjacent trees did not touch or interact.

Trees at Woodville and Tikokino were poplar (Populus deltoides x P. nigra) clone 'Tasman' and were established by planting 2.5-3.0 m-long vegetative poles (Wilkinson 1999). The height of poles above the ground after planting was 1.7-2.2 $\mathrm{m}$. The trees at Ruakura and Poukawa were Italian alder (Alnus cordata), a nitrogen (N)-fixing species, and were established by transplanting nursery-raised seedlings of 0.5-0.7 m height. Soil samples collected within 5 years after planting at each site indicated that PT and adjacent Open systems had generally similar physical and chemical attributes (not presented). Some of the trees had received minor silviculture (e.g. one pruning at Woodville and Tikokino), and all sites were grazed intermittently with sheep and sometimes cattle.

\section{Measurements}

Soil bulk density (BD), root mass density (RMD) and $\mathrm{C}$ concentration (CC) were determined in soil core samples collected from PT (2 reps) and Open pasture (3 reps) systems at each site. Within each PT system, sample positions were at the centre of approximate squares defined by four trees being from two adjacent transects (radii/spokes) of the Nelder design and the accompanying inner and outer arcs (Figure 1). Soil coring was conducted in 2012 at Ruakura on 26-28 November, at Poukawa and Tikokino on $3^{\text {rd }}$ and $4^{\text {th }}$ December, and at Woodville on $5^{\text {th }}$ December. Separate core samples of $100 \mathrm{~mm}$ or $25 \mathrm{~mm}$ diameter, depending on site conditions, were collected at five depths $(0-75,75-150,150-$

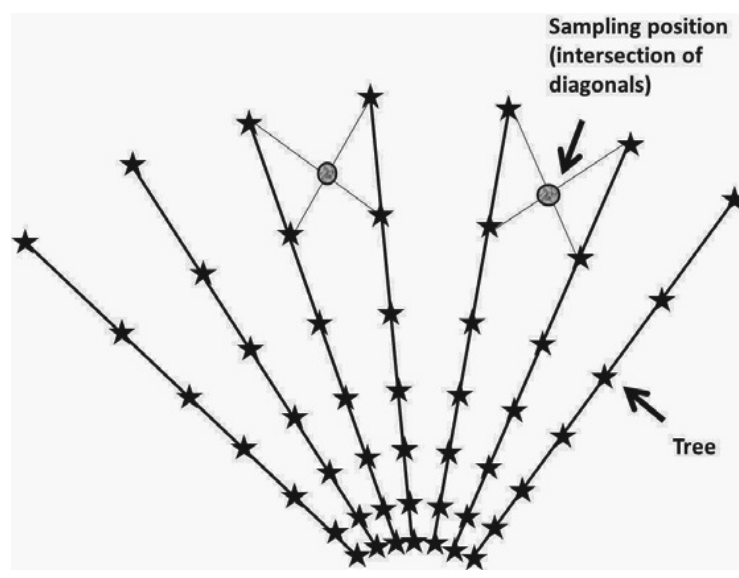

Figure 1 Location of soil sampling positions at lowest tree density in Nelder planting designs at four North Island sites.

$300,300-600,600-1000 \mathrm{~mm}$ ) for determination of root mass (results not presented) and soil C. Samples for BD within each depth increment were collected from nearby excavated pits. Trunk (stem) diameter at breast height (DBH; $1.4 \mathrm{~m}$ above ground) of the four trees in each of the two squares at each site was also measured.

\section{Soil sample processing and statistical analyses}

Soil bulk density: Samples were dried at $105^{\circ} \mathrm{C}$ for $24 \mathrm{~h}$ and then weighed. Estimates of BD $\left(\mathrm{g} / \mathrm{cm}^{3}\right)$ were adjusted if roots and pebbles occurred in samples.

Soil carbon concentration (CC) and mass: Samples were dried at $30^{\circ} \mathrm{C}$ for $24 \mathrm{~h}$ and then passed through a $2 \mathrm{~mm}$ sieve. Subsamples were analysed for CC using a LECO CNS-2000 dry combustion analyser at $1330^{\circ} \mathrm{C}$. Soil carbon mass $(\mathrm{CM})$ at each soil depth increment was calculated by multiplying the soil $\mathrm{CC}(\%)$ by its corresponding $\mathrm{BD}$ and expressing it in units of $\mathrm{t} \mathrm{C} /$ ha. Total carbon mass to $1 \mathrm{~m}$ soil depth (TCM) was calculated by summing the $\mathrm{CM}$ contained within each of the five incremental depths. The percentage of TCM at 300-1000 $\mathrm{mm}$ depth was calculated.

Attributes of BD, CC, CM, and TCM were analysed separately for each site using analysis of variance. Models for $\mathrm{BD}, \mathrm{CC}$ and $\mathrm{CM}$ comprised sources of variation of system (1 degree of freedom (df)), depth (4 $\mathrm{df})$, system $\times$ depth interaction $(4 \mathrm{df})$, and residual (15 df). The model for TCM comprised system (1 df) and residual (3 df). Mean DBH and standard errors (s.e.) were calculated for trees at each site.

\section{Results}

\section{Diameter at breast height}

Mean tree DBH at Tikokino $(47.3 \pm 0.4 \mathrm{~cm}$; mean \pm s.e.) was $20-25 \mathrm{~cm}$ greater than at the other sites, being 
$27.5 \pm 0.1 \mathrm{~cm}$ at Ruakura, $22.0 \pm 0.8 \mathrm{~cm}$ at Poukawa and $24.1 \pm 2.5 \mathrm{~cm}$ at Woodville.

\section{Soil bulk density}

BD at Poukawa (1.1-1.4 g/ $\left.\mathrm{cm}^{3}\right)$ and Woodville (1.1-1.7 $\left.\mathrm{g} / \mathrm{cm}^{3}\right)$ was up to twice that at Ruakura $\left(0.6-1.0 \mathrm{~g} / \mathrm{cm}^{3}\right)$ and Tikokino $\left(0.6-1.0 \mathrm{~g} / \mathrm{cm}^{3}\right)$. Means for PT and Open systems followed similar trends and within sites, $\mathrm{BD}$ did not vary significantly between systems (Table 1). At all sites, BD increased with increasing depth (not presented).

\section{Soil carbon concentration}

The highest CCs were found at Ruakura of up to $16 \%$ and they were up to 4 -fold greater than those at Woodville and Poukawa, where values were $4 \%$ or less (Figure 2). Soils at Tikokino had CCs of up to $11 \%$. Mean CCs of systems at Tikokino were intermediate between values at Ruakura and those at Poukawa and Woodville (Table 1). At Poukawa, the PT system had two-thirds less CC than Open at 300-600 mm depth (system $\times$ depth interaction), whereas there were no significant differences between systems at the other depths. At the other sites, $\mathrm{CC}$ decreased with increasing depth (Figure 2).

\section{Soil carbon mass}

Mean CM was highest at Ruakura, followed by Tikokino, and lowest values were found at Poukawa and Woodville (Table 1). PT had lower CM than Open systems at Poukawa and Woodville whereas elsewhere, there was no significant difference between systems. CM varied with depth at all sites but there was no consistent pattern (not presented). Across sites, CM at 300-1000 mm depth comprised $44-50 \%$ of TCM (Table 1 ).

\section{Total carbon mass}

Highest mean TCM was estimated at Ruakura and Tikokino of 328-455 tonnes $\mathrm{C} / \mathrm{ha}$ which exceeded values at Poukawa and Woodville of 120-202 tonnes C/ha (Table 1). The PT system had 37\% less TCM than the Open system at Poukawa, whereas at the other sites, there were no significant differences between systems.

\section{Discussion}

Previous research has shown that wide-spaced poplars modify the above- and below-ground microenvironment of hill pastoral systems (Guevara-Escobar et al. 2002; Douglas et al. 2006a) whereas there has been negligible investigation of the impact of alders (Sharma et al. 2009), and none when they are planted at

Table 1 Bulk density, carbon concentration, and carbon mass averaged over 5 soil depth increments, and total soil carbon mass (tonnes $\mathrm{C} / \mathrm{ha}$ ) to $1000 \mathrm{~mm}$ depth, in Pasture-tree and Open pasture systems at four North Island sites. Tree species at each site is indicated in parentheses. Data for carbon mass at Ruakura, Tikokino and Woodville are back-transformed from logarithms.

\begin{tabular}{|c|c|c|c|c|c|}
\hline System & Replicates & Poukawa (alder) & Ruakura (alder) & Tikokino (poplar) & Woodville (poplar) \\
\hline \multicolumn{6}{|c|}{ Bulk density $\left(\mathrm{g} / \mathrm{cm}^{3}\right)$} \\
\hline Pasture-tree & 10 & 1.29 & 0.79 & 0.75 & 1.39 \\
\hline Open pasture & 15 & 1.33 & 0.72 & 0.77 & 1.40 \\
\hline Probability & & 0.26 & 0.12 & 0.42 & 0.64 \\
\hline \multicolumn{6}{|c|}{ Carbon concentration (\%) } \\
\hline Pasture-tree & 10 & 1.7 & 8.3 & 6.5 & 1.9 \\
\hline Open pasture & 15 & 2.0 & 8.6 & 6.6 & 2.3 \\
\hline Probability & & $<0.01$ & 0.73 & 0.95 & 0.11 \\
\hline \multicolumn{6}{|c|}{ Carbon mass (tonnes/ha) } \\
\hline Pasture-tree & 10 & 24.0 & 81.2 & 64.0 & 29.6 \\
\hline Open pasture & 15 & 37.8 & 71.3 & 65.0 & 37.9 \\
\hline Probability & & $<0.01$ & 0.32 & 0.90 & 0.04 \\
\hline \multicolumn{6}{|c|}{ Total carbon mass (tonnes/ha) } \\
\hline Pasture-tree & 2 & 120 & 455 & 328 & 154 \\
\hline Open pasture & 3 & 189 & 374 & 352 & 202 \\
\hline Probability & & $<0.01$ & 0.41 & 0.78 & 0.22 \\
\hline Deep carbon (\%) ${ }^{a}$ & & 49 & 44 & 50 & 46 \\
\hline
\end{tabular}



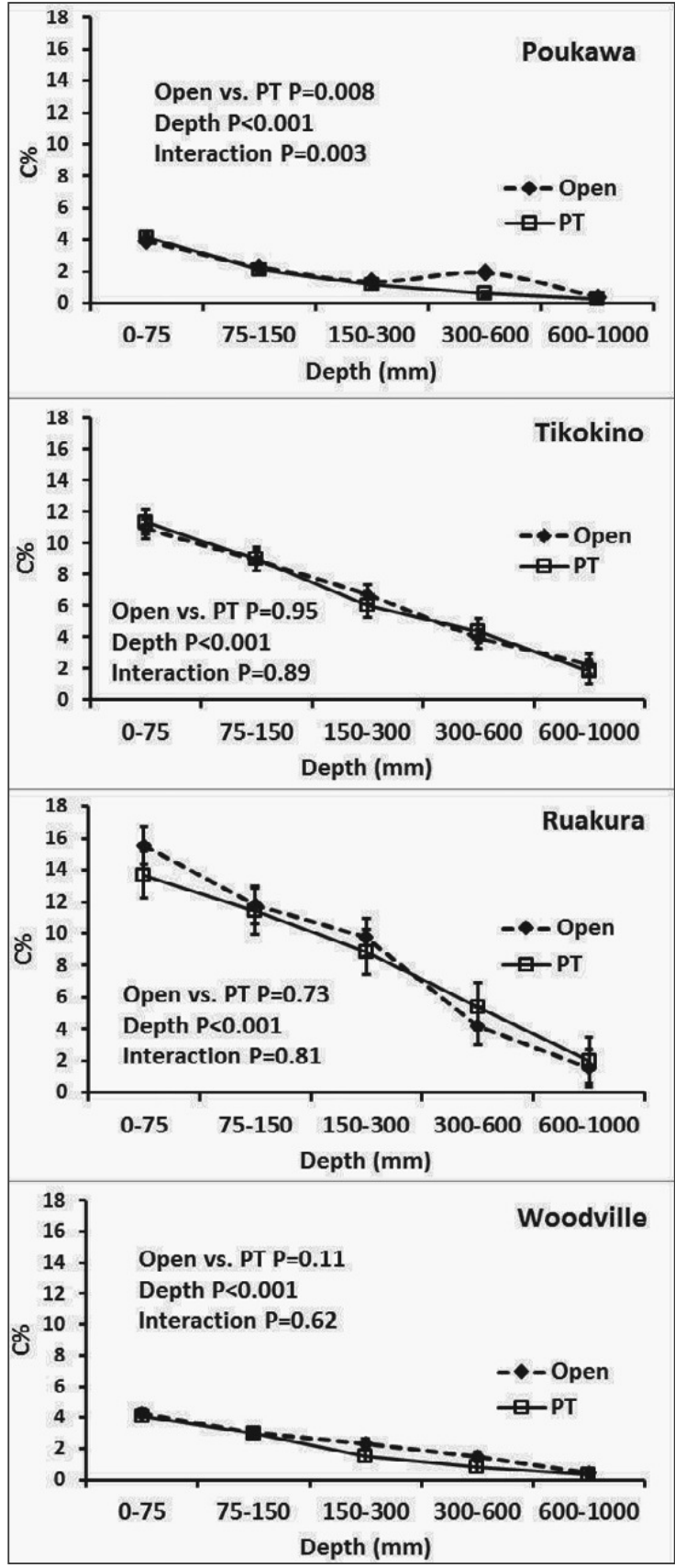

Figure 2 Mean soil carbon (C) concentration (\%, vertical axis) to $1000 \mathrm{~mm}$ depth in Pasture-tree (PT) and Open pasture systems at four North Island sites.

wide spacings. This study determined the contribution of these species to soil carbon stocks in pastoral systems, thereby complementing limited earlier work with poplar and providing new knowledge and understanding for alder.

The soils at Tikokino and Ruakura were of volcanic origin whereas those at Poukawa and Woodville were of sedimentary origin. This accounts to a large degree for the lower mean soil BD and higher mean CC at Tikokino and Ruakura than at Poukawa and Woodville, and mean $\mathrm{CM}$ at Poukawa and Woodville (32 or 34 tonnes C/ha) being about half that at Tikokino and Ruakura (65 or 75 tonnes $\mathrm{C} / \mathrm{ha}$ ). Up to half of TCM occurred at 300-1000 $\mathrm{mm}$ depth. This provided compelling evidence of the need to measure carbon deeper in soil profiles. Carbon at greater depth may be more stable through greater resistance to biodegradation and have longer residence times (Lorenz \& Lal 2005), providing a valuable contribution to greenhouse gas mitigation.

The lack of differences between PT and Open systems in soil BD (all sites), CC (all sites except Poukawa), and CM (Ruakura and Tikokino) may have been because the sampling positions within the PT systems were at the centre of approximate squares in the Nelder designs, where tree root presence would have been lower than closer to trees. At Ruakura, with the slightly higher tree density than at the other sites, sampling positions were about $6.5 \mathrm{~m}$ from any tree and at the other sites they were about $8 \mathrm{~m}$. In another study on slopes of approximately $20^{\circ},>2 \mathrm{~mm}$ diameter roots of 'Veronese' poplar trees aged up to 11.5 years (DBH $<30 \mathrm{~cm}$ ) extended more than $14 \mathrm{~m}$ from the tree trunk, but most were less than $10 \mathrm{~m}$ from the trunk (McIvor et al. 2009). Tree roots were detected in core samples in this study but their presence and unknown decomposition products appeared insufficient to effect change compared with processes in the Open. Also, the up to 2-fold greater DBH of trees at Tikokino than at the other sites may have increased root mass and length (McIvor et al. 2008) but this did not advantage PT over the Open system for the soil attributes measured.

The results showed that there was no statistical difference in mean total soil carbon mass between the Pasture-poplar and Open pasture systems at Tikokino and Woodville. In contrast, the effect of the alder trees on soil carbon was more variable, with no significant difference in mean TCM between PT and Open systems at Ruakura versus a reduction in TCM of $37 \%$ in the PT compared with the Open system at Poukawa. These findings did not support those reviewed by Vesterdal et al. (2013) who found consistent effects of tree species on soil carbon stocks. This may be because of variation in geo-climatic factors, tree characteristics (e.g. species, age, stand density, litter inputs and decomposition rates), and sampling protocols.

Tree species could be added as a factor, in addition to tree biomass, in the building of carbon inventories. To confirm and extend the present study conducted on flat sites, comparisons between PT and Open systems need to be conducted on the shallower soils on hillslopes and soils found in gully systems. While using trees with their frequently deeper and thicker roots than grassland 
species provides potential enhancement of deep soil carbon stocks, the findings from this study suggest that this is an oversimplification of the potential impact planting trees into a pastoral soil has on soil carbon stocks.

\section{Conclusions}

The effects of wide-spaced trees on pastoral soil carbon stocks varied depending on the tree species and site. Whereas the influence of alder on soil carbon varied between two sites, for poplar at two other sites, there was no significant difference between systems with and without trees. Given the extensive plantings of poplar on millions of hectares of eroding hill country, building a more complete inventory and a better understanding of the processes contributing to the change in soil carbon stocks warrants further study.

\section{ACKNOWLEDGEMENTS}

Funding from the Ministry for Primary Industries (Sustainable Land Management and Adaptation to Climate Change (SLMACC) research programme) and Sustainable Land Use Research Initiative (SLURI). Farmers and managers who allowed access to the sites. Catherine Lloyd-West, AgResearch Grasslands, for statistical analyses.

\section{REFERENCES}

Baah-Acheamfour, M.; Carlyle, C.N.; Bork, E.W.; Chang, S.X. 2014. Trees increase soil carbon and its stability in three agroforestry systems in central Alberta, Canada. Forest Ecology and Management 328: 131-139.

Douglas, G.B.; McIvor, I.R.; Manderson, A.K.; Koolaard, J.P.; Todd, M.; Braaksma, S.; Gray, R.A.J. 2013. Reducing shallow landslide occurrence in pastoral hill country using wide-spaced trees. Land Degradation and Development 24: 103-114.

Douglas, G.B.; Walcroft, A.S.; Hurst, S.E.; Potter, J.F.; Foote, A.G.; Fung, L.E.; Edwards, W.R.N.; van den Dijssel, C. 2006a. Interactions between widely spaced young poplars (Populus spp.) and introduced pasture mixtures. Agroforestry Systems 66: 165-178.

Douglas, G.B.; Walcroft, A.S.; Hurst, S.E.; Potter, J.F.; Foote, A.G.; Fung, L.E.; Edwards, W.R.N.; van den Dijssel, C. 2006b. Interactions between widely spaced young poplars (Populus spp.) and the understorey environment. Agroforestry Systems 67: 177-186.

Dube, F.; Espinosa, M.; Stolpe, N.; Zagal, E.; Thevathasan, N.; Gordon, A. 2012. Productivity and carbon storage in silvopastoral systems with Pinus ponderosa and Trifolium spp., plantations and pasture on an Andisol in Patagonia, Chile. Agroforestry Systems 86: 113-128.
Eswaran, H.; van den Berg, E.; Reich, P.B.; Kimble, J.M. 1995. Global soil carbon resources. pp. 27-43. In: Soils and global change. Eds. Lal, R.; Kimble, J. M.; Levine, E.; Stewart, B. A. CRC Press Lewis Publishers, Boca Raton.

Guevara-Escobar, A.; Kemp, P.D.; Mackay, A.D.; Hodgson, J. 2002. Soil properties of a widely spaced, planted poplar (Populus deltoides)-pasture system in a hill environment. Australian Journal of Soil Research 40: 873-886.

Lal, R. 2004. Agricultural activities and the global carbon cycle. Nutrient Cycling in Agroecosystems 70: 103-116.

Lorenz, K.; Lal, R. 2005. The depth distribution of soil organic carbon in relation to land use and management and the potential of carbon sequestration in subsoil horizons. pp. 35-66. In: Advances in Agronomy. Ed. Donald, L. S. Academic Press,

McIvor, I.; Douglas, G.; Dymond, J.; Eyles, G.; Marden, M. 2011. Pastoral hill slope erosion in New Zealand and the role of poplar and willow trees in its reduction. pp. 257-278. In: Soil erosion issues in agriculture. Eds. Godone, D.; Silvia, S. InTech - Open Access Publisher http://www.intechopen. com/articles/show/title/pastoral-hill-slope-erosionin-new-zealand-and-the-role-of-poplar-and-willowtrees-in-its-reduction,

McIvor, I.R.; Douglas, G.B.; Benavides, R. 2009. Coarse root growth of Veronese poplar trees varies with position on an erodible slope in New Zealand. Agroforestry Systems 76: 251-264.

McIvor, I.R.; Douglas, G.B.; Hurst, S.E.; Hussain, Z.; Foote, A.G. 2008. Structural root growth of young Veronese poplars on erodible slopes in the southern North Island, New Zealand. Agroforestry Systems 72: 75-86.

Nelder, J.A. 1962. New kinds of systematic designs for spacing experiments. Biometrics 18: 283-309.

Pérez-Cruzado, C.; Mansilla-Salinero, P.; RodríguezSoalleiro, R.; Merino, A. 2012. Influence of tree species on carbon sequestration in afforested pastures in a humid temperate region. Plant and Soil 353: 333-353.

Power, I.L.; Thorrold, B.S.; Balks, M.R. 2003. Soil properties and nitrogen availability in silvopastoral plantings of Acacia melanoxylon in North Island, New Zealand. Agroforestry Systems 57: 225-237.

Sharma, G.; Sharma, R.; Sharma, E. 2009. Impact of stand age on soil $\mathrm{C}, \mathrm{N}$ and $\mathrm{P}$ dynamics in a 40-year chronosequence of alder-cardamom agroforestry stands of the Sikkim Himalaya. Pedobiologia 52: 401-414.

Van Kraayenoord, C.W.S.; Hathaway, R.L. Eds. 1986. Plant materials handbook for soil conservation. Volume 2, Introduced plants. Water and Soil Directorate, Ministry of Works and Development, Wellington. 
Vesterdal, L.; Clarke, N.; Sigurdsson, B.D.; Gundersen, P. 2013. Do tree species influence soil carbon stocks in temperate and boreal forests? Forest Ecology and Management 309: 4-18.
Wilkinson, A.G. 1999. Poplars and willows for soil erosion control in New Zealand. Biomass and Bioenergy 16: 263-274.

Young, A. 1997. Agroforestry for soil management. CAB International, Wallingford. $320 \mathrm{pp}$. 